\title{
DEMOGRAPHIC RESEARCH
}

\section{VOLUME 44, ARTICLE 7, PAGES 157-188 \\ PUBLISHED 28 JANUARY 2021}

https://www.demographic-research.org/Volumes/Vol44/7/

DOI: 10.4054/DemRes.2021.44.7

Research Article

\section{Educational assortative mating and the decline of hypergamy in 27 European countries: An examination of trends through cohorts}

\section{Dávid Erát}

\section{๑) 2021 Dávid Erát.}

This open-access work is published under the terms of the Creative Commons Attribution 3.0 Germany (CC BY 3.0 DE), which permits use, reproduction, and distribution in any medium, provided the original author(s) and source are given credit.

See https://creativecommons.org/licenses/by/3.0/de/legalcode. 


\section{Contents}

$\begin{array}{lll}1 & \text { Introduction } & 158\end{array}$

$2 \quad$ Theoretical background 158

3 Previous results and research hypothesis 162

$4 \quad$ Data and methods 163

5 Results 165

6 Summary 174

$7 \quad$ Acknowledgements 176

$\begin{array}{ll}\text { References } & 177\end{array}$

$\begin{array}{ll}\text { Appendix } & 184\end{array}$ 


\title{
Educational assortative mating and the decline of hypergamy in 27 European countries: An examination of trends through cohorts
}

\author{
Dávid Erát ${ }^{1}$
}

\begin{abstract}
BACKGROUND

Theories of partner selection emphasize the principal role of available partners in the relationship market. As education is a common socioeconomic attribute through which individuals choose a mate, macrostructure theory highlights the importance of the asymmetric change in educational attainment seen in Europe. As women increasingly participate in tertiary education, this restructuring might result in the decline of traditional hypergamous unions.
\end{abstract}

\section{OBJECTIVE}

We aim to verify previous results confirming the decline of educational hypergamy and the rise of hypogamy, which has been found to be related to women's growing educational advantage. We also wish to provide a current picture of this process in Europe by looking at the youngest cohort available during the analysis.

\section{METHODS}

We pooled nine waves of the European Social Survey and examined trends in seven cohorts. Apart from simple percentage differences in education, we reconstructed the indices of female educational advantage (F-index) and the prevalence of hypergamy $(\mathrm{H}-$ index), with provided correlation statistics and fitted linear trend lines.

\section{RESULTS}

Our results corroborated the findings of previous multi-country analyses. In nearly all selected countries, women were more present in higher education than men, resulting in a uniform increase in the female educational advantage. Parallel to this, hypergamy declined through the cohorts, which correlated with women's emerging educational lead.

\section{CONTRIBUTION}

Our results verify the findings from previous years, using a newer dataset and detailed cohort perspective, and confirm the decline of hypergamy as women gain advantage in

\footnotetext{
${ }^{1}$ University of Pécs, Institute of Social and Media Studies, Department of Sociology and Doctoral School of Demography and Sociology, Hungary. Email: erat.david@gmail.com.
} 
education, with only four countries out of 27 showing some remnants of a male educational lead.

\section{Introduction}

For a long time, social scientists have noted that there is a tendency for people to select partners with a particular characteristic, such as educational attainment, occupation, wage, race, religion, or attitudes (Hout 1982; Mare 1991; Kalmijn 1991; Sweeney and Cancian 2001). This propensity for non-random partnering poses the age-old question: who chooses whom? In this study, we contribute to answering this question by examining partnership formation by educational attainment, and, more precisely, how the composition of the pool of available partners forms educational assortative mating in 27 European countries. We propose that the reversal of the gender gap in education seen in Europe has restructured the relationship market, resulting in the decline of traditional unions where men have an educational advantage over women.

Because this research question has been examined and verified by multiple works from Europe in recent years, principally by Esteve, García-Román, and Permanyer (2012), Esteve et al. (2016), and De Hauw, Grow, and Van Bavel (2017), our work mainly aims to replicate the trends seen in these previous studies and to expand knowledge on the issue by using a detailed cohort perspective with newly available data provided by the European Social Survey. Our findings corroborate previous results, revealing the increasing educational advantage of women and the continual decline of educational hypergamy, while highlighting some nations - primarily Austria, Germany, and Switzerland - as lagging behind the general trend. Although the results point out the strong effect of relationship market composition on partnering, the findings should be considered along with other processes, such as the changing nature of individual preferences and the effect of societal norms on the forming of relationships.

\section{Theoretical background}

As noted in the introduction, partner selection is not an entirely random process, as persons aim to choose others based on certain preferences. From the numerous possible criteria, socioeconomic attributes (such as income, wealth, occupation, prestige, and education) are often emphasized because they influence the status and well-being of the individual and the couple due to the pooling of resources in a relationship (Parsons 1942, 1955a, 1955b; South 1991; Kalmijn 1998; Bukodi 2002). This effect on status has also 
been noted by social stratification researchers, who identify partnerships (primarily marriages) as potential avenues of upward social mobility, recognizing that a 'good match' has the opportunity to substantially improve someone's status position (Sorokin 1972; Hout 1982).

Based on the relative socioeconomic standing of partners, we can distinguish homogamy and heterogamy (Kalmijn 1998; Henz and Mills 2017). A relationship is considered homogamous if the partners have an equal or similar status, while heterogamy indicates a dissimilarity along a selected attribute. Amongst heterosexual heterogamous couples, hypergamy traditionally designates that the male has a better position than his partner, and hypogamy means that the female is in an advantage compared to her partner. In itself, the categorization implies a most interesting question: which type of arrangement is preferred by men and women?

A useful theoretical viewpoint for understanding partner selection preferences and patterns is Becker's economic approach, which sees a relationship as a form of trade established by individuals who aim to increase their advantages compared to staying single (Becker 1973, 1974, 1981). In a societal context where relationships primarily involve breadwinner men and women who are not employed, men offer paid work to trade for women's unpaid work, care, and higher involvement in child-rearing (Becker 1981). This division stems from intrinsic advantages and disadvantages, as women face an uneven time investment on their part, primarily in childcare, while in turn men are more likely to do paid work outside the home. Additionally, the gender differences in the exchange of goods are supported by a social component, as parents socialize their children gender-specifically to expect that they have to provide certain resources, which makes some investments in life more attractive to them (Becker 1981). Therefore, using Becker's theory, it can be assumed that women generally prefer to partner with men who have superior socioeconomic resources (for example, a high level of education), while men choose women not for their labour market potential, but based on their ability to fulfil unpaid roles, such as child-rearing and household tasks. From the previously discussed arrangements of relative socioeconomic standing, these preferences highlight hypergamy as the primary desired type of union for both genders.

While Becker's approach implies that socioeconomic hypergamy is the preferred relationship type for men and women, criticism of this economic viewpoint has pointed to the societal change in relationships, where women are not only concerned with unpaid work and childcare. Oppenheimer noted that the employment of women is increasingly widespread and advantageous to couples, while single-worker households are increasingly rare and disadvantaged (1977). The drawback of only having one earner is apparent when considering 'real-life' situations: these couples are more exposed to the risk of considerable loss of status and decreased well-being in the event of losing the main (and often only) earner, while, in general, dual-earner couples can achieve higher 
living standards and are more flexible in the face of unforeseeable incidents (Oppenheimer 1994, 1997; Sweeney 2002). Thus, a dual-earner arrangement may become more preferable and women might be more likely to invest in market-related skills such as education, while men might also develop a preference for women having socioeconomic resources - implying that hypergamy might lose its appeal.

So far, we have established that individuals have preferences regarding their partner's socioeconomic resources, as they influence their status and well-being; and that from Becker's point of view, hypergamy is the principal preferred type of arrangement for men and women. While socioeconomic resources and partner-selection preference are certainly important, we have only considered individual desires as a determinant of partner choice, which would imply that persons looking for a partner face no other limitations in their search. However, this is patently not the case.

As conceptualized by Winch decades ago, partner selection is a phenomenon where an individual chooses a preferred partner from a "restricted segment of the population", which he named the "field of eligibles" (1958: 14; Kerckhoff 1964: 290-291). Similarly, Huckfeldt posited that interaction is shaped by the social composition of the "relevant environment" (1983: 653). Regarding sexual partners, Laumann et al. speak in similar terms about sexual networks and their social structure (1994). In short, partner selection is limited by the structural conditions of the so-called relationship market, which operates by the logic of numbers as the term encompasses the number and quality of potential mates whom the individual has a chance to meet (Kalmijn 1994, 1998; Bukodi 2002; Rosenfeld 2002).

Formally defined, the relationship market is the physical and symbolical meeting place of men and women willing to enter a union, who are generally in geographic and social proximity to each other (Stevens 1991; Cabré 1993; Birkelund and Heldal 2003; Esteve and Cortina 2006). The relationship market can also be understood - in more demographic terms and without physical or social restriction - as the part of the population who are at risk of entering a relationship. Theories of this market consider three main aspects: the relative size of the various social groups in a society, which facilitates or hinders homogamy or heterogamy; the geographical distribution of the potential mates, as the number of eligible partners differs between cities and rural villages, economically advanced and underdeveloped counties, and even city districts; and, finally, the social structure of the spaces individuals inhabit on a daily basis.

The macrostructure theory of Blau (1977) is a comprehensive and often employed approach to understanding the relationship market. Blau defines the macrostructure of societies as "the multidimensional space of social positions among which people are distributed and affect their social relations" (1977: 30). While status-related attributes might act as barriers or entryways to certain social relationships, the size of the societal groups generally has the most substantial effect. Blau elaborates that, logically, smaller 
groups tend to have more intergroup connections, as a small group size facilitates more interaction with outsiders; while, conversely, members of large groups tend to have more homogeneous social networks (1977: 35-40). While Blau offers a compelling argument to consider relative group size as a factor in partner selection, some scholars note that, for relationships specifically, the composition of certain markets could be more important, as people spend most of their time in smaller functional spaces such as neighbourhoods, workplaces, family networks, and, most notably in the past few decades, education (McFarland 1975; Kalmijn 1998; Kalmijn and Flap 2001). ${ }^{2}$

Among the possible socioeconomic attributes, education has often been examined, and with good reason. First, education is related to the individual's family background and future success; therefore (based on the previously introduced concepts), it is a major component of social stratification and can be a desired quality in an individual (Breen et al. 2009; Breen 2010; Autor 2014; Posselt and Grodsky 2017). Second, education is an increasingly substantial part of the individual's life course, as people spend a good amount of their life in educational institutions, causing it to parallel the transition to adulthood and the search for a potential mate (Mare 1991; Blossfeld and Timm 2003).

However, in recent decades a certain asymmetry has become apparent. In Europe, and particularly in higher education, women have increasingly begun to outnumber men (Vincent-Lancrin 2008), and as a consequence higher-educated women have entered the relationship market in greater numbers. From the perspective of the macrostructure theory, this imbalanced change in the relationship market might result in different mating patterns as the relative size of certain groups is altered. This possibility highlights the importance of studying the relationship market, as the educational transformation may force a change in assortative mating regardless of preferences or norms (Van Bavel 2012; Nomes and Van Bavel 2017).

Furthermore, if the asymmetric change in education brings about the transformation of mating patterns and the rise of hypogamy, it can also have implications for relationship dynamics. Becker's economic theory proposes that a relationship is established because partners aim to increase their gains compared to staying single, and that men primarily offer their socioeconomic resources in exchange for women's unpaid work. From Becker's viewpoint, this mutually beneficial trade-off creates interdependence, which increases the relationship's quality and decreases the risk of its dissolution (1981). However, as education is linked to overall socioeconomic resources, women can be expected to become less reliant on men (Becker, Landes, and Michael 1977; Becker 1981, 1985).

This independence can manifest itself in multiple ways. For example, if entering into a relationship no longer involves a substantial increase in socioeconomic well-being,

${ }^{2}$ Besides these traditional markets, in recent years, online dating has also gained importance as a relationship
market. See Kreager et al. 2014; Eichenberg, Huss, and Küsel 2017; Bruch and Newman 2018; Berger 2019 . 
women might decide to stay single longer or permanently. Also, based on this, it may be easier for women with available socioeconomic resources and market skills to leave relationships that they deem unsatisfactory. The latter link (often called the independence hypothesis or independence effect, see Oppenheimer 1997) between separation and hypogamy has been confirmed in several recent studies, highlighting the importance of examining assortative mating patterns in the study of relationship dissolution (Teachman 2002; Kalmijn 2003; Lyngstad 2004; Frimmel, Halla, and Winter-Ebmer 2013; Blossfeld 2014; Maenpaa and Jalovaara 2014). Additionally, maintaining a non-hypergamous relationship in which the woman is an earner or even the primary breadwinner might be more difficult if the couple face external pressures from a gender-traditional society that looks negatively on men and women who do not fulfil and display the prescribed gender norms and behaviours (West and Zimmerman 1987; Brines 1994; Eagly and Wood 1999; Tichenor 2005).

\section{Previous results and research hypothesis}

In summary, theories suggest that educational assortative mating is largely influenced by the available pool of partners in the relationship market, which limits partner selection opportunities and thereby affects the educational composition of relationships, regardless of individual preferences. In recent years, many studies have found evidence of this ongoing process in Europe.

Esteve, García-Román, and Permanyer examine census data from 56 countries, 11 of them European, focusing on the association between female educational advantage and the number of hypergamous relationships (2012). For all the countries they find strong evidence that the two are associated: that is, as the average level of women's education grows hypergamy begins to decline, and traditional marriages are outnumbered by educationally hypogamous couples. This is supported by Esteve et al., with an extended roster of countries (2016). Results of this study suggest not only that women increasingly participate in tertiary education and partner hypogamously, but also that Europe is spearheading this change in assortative mating patterns. Esteve et al. also find signs of the consequences of this structural change: in the 27 examined European countries, women become main breadwinners more frequently, and egalitarian attitudes are more prominent. Finally, De Hauw, Grow, and Van Bavel employ multilevel analysis to unravel the link between the emerging educational gender gap and changes in educational assortative mating in Europe (2017). Their descriptive results show that in older cohorts, homogamy is most common, followed by hypergamy, and while homogamy retains its dominance, hypogamy has become widespread in most of the 28 nations by the youngest examined cohort (1970-1979). Their regression modelling 
supports this apparent change: as the gender gap grows, women are more likely to partner down in terms of education. This overall dominance of homogamy and the emergence of educational hypogamy as the second most prominent relationship type in Europe is supported by several country-specific studies (Correia 2003; Esteve and Cortina 2006; Katrňák 2008; Dribe and Nystedt 2013; Krzyzanowska and Mascie-Taylor 2014; Maenpaa 2015). While our analysis is mainly concerned with European countries, it should be noted that the European trends are in line with findings from other parts of the world, as results also point at the decline of hypergamy in the United States (Qian 2016), in Asia (Borkotoky and Gupta 2016; Fukuda, Yoda, and Mogi 2019), in Latin America (Ganguli, Hausmann, and Viarengo 2014), and in sub-Saharan Africa (Pesando 2019).

In short, multiple results confirm the changing trend of educational assortative mating due to the transformation of educational composition, resulting in the decline of hypergamy. Because in Europe this assumption for married and non-married couples is neither new nor highly debated, the primary aim of this study is to replicate and reinforce these results, and examine them further with a cohort-based assessment. Stemming from the processes and results described above, our hypothesis is that the clear negative association between the rising educational level of women and the decline of hypergamy will be replicated and the results of the previously presented works confirmed (principally those by Esteve, García-Román, and Permanyer (2012), Esteve et al. (2016), and De Hauw, Grow, and Van Bavel (2017)).

\section{Data and methods}

For our analysis we used all nine available waves of the European Social Survey (20022018) (European Social Survey 2020). The European Social Survey is a freely available representative cross-national survey conducted biennially since 2001, covering a wide range of permanent and rotating themes. Because it includes basic social and demographic variables about a person and his or her partner, it provides an adequate source of data on the individual and the relative level of completed education needed for the analyses.

To assess the composition of the relationship market, we selected all individuals (not just those who were in a relationship) who provided information about their level of completed education. Separately, to measure educational assortative mating patterns, all individuals in a relationship (marriage or cohabitation) were considered if they provided data about their own and their partner's completed educational attainment. We excluded respondents under the age of 25 and above the age of 55 for all analyses in order to limit the number of persons who might substantially advance their education in the future (for example, from a high school diploma to a university degree), which could introduce 
considerable bias to the presented results, and to reduce the effect of education and cohort-specific biases of mortality, union formation, and partnership dissolution. Because we focus on the trends visible through cohorts, we pooled all waves $(2002,2004,2006$, $2008,2010,2012,2014,2016,2018)$ into one dataset. The data was weighted based on the guidelines provided by the ESS to accommodate for biases stemming from population size, inclusion probability, sampling errors, and non-response errors (see European Social Survey 2014). Countries in the ESS were omitted if they participated in less than four waves $^{3}$ of the ESS to avoid errors caused by small sample sizes. In the end, 27 European countries were included in the analyses, as detailed in Tables A-1 and A-2.

To measure the relative level of completed education we first constructed a threecategory variable based on the available ISCED (International Standard Classification of Education) categories in the ESS data. Those belonging in ISCED 0-2 were coded 'low', those in ISCED 3-4 were designated 'medium', while respondents with ISCED 5 or higher educational attainment were classified as 'high'. Although a higher number of categories might shed light on more subtle processes, this simple three-way differentiation ensures proper distinction without fragmenting the available dataset. Creating this variable for the respondent's partner as well allowed us to classify couples into three groups: those with an equal level of education (homogamous) and couples in which men (hypergamous) or women (hypogamous) had a higher educational attainment. Additionally, we recreated two previously used (Esteve, García-Román, and Permanyer 2012) indices for all nations and cohorts to examine the composition of the relationship market, and to measure the prevalence of hypergamy. The first, called index of female educational advantage (F-index) is calculated as

$$
F=\frac{p_{f}^{3}\left(p_{m}^{1}+p_{m}^{2}\right)+p_{f}^{2} p_{m}^{1}}{1-\left(p_{f}^{1} p_{m}^{1}+p_{f}^{2} p_{m}^{2}+p_{f}^{3} p_{m}^{3}\right)}
$$

where $p_{f}^{e}$ and $p_{m}^{e}$ denote the proportions of women $(f)$ and men $(m)$ in educational category $e=1, \ldots 3$. This index represents the probability that of a randomly chosen male and female the latter has the higher level of education, with 0.5 indicating equality. Again, it should be emphasized that the F-index is calculated for all respondents and not just those who are in a partnership, to properly reflect relationship market conditions. The second indicator showing the prevalence of hypergamy (H-index) is simply defined as

$$
H=\ln \frac{A}{B}
$$

${ }^{3}$ The omitted nations are: Albania, Croatia, Iceland, Kosovo, Latvia, Luxembourg, Montenegro, Romania, Serbia, and Turkey. Additionally, Israel was not included as the analyses only focus on Europe. 
where A denotes the number of hypergamous and B the number of hypogamous couples. If the $\mathrm{H}$-index is lower than 0 the hypogamic couples outnumber the hypergamous couples amongst non-homogamous couples. Based on the selected data and measures, the results will be presented in three parts: first, we will determine whether educational expansion has resulted in women catching up with or overtaking men in the overall level of education transforming the relationship market; second, we will assess how the structure of relationships has changed by examining hypergamy trends; and, third, we will test the main hypothesis of the current work - the negative link between the former and the latter.

\section{Results}

One of the most frequently emphasized aspect of the educational expansion in Europe is that while there has been an increase in the average level of education, women have entered higher education in greater numbers and therefore have reached equality with men education-wise, or have even surpassed them. Esteve, García-Román, and Permanyer (2012) verify this by looking at the percentage of men and women with tertiary education, and De Hauw, Grow, and Van Bavel (2017) do so by looking at tertiary enrolment statistics. To confirm this assumption in a simple way, Figure 1 and Table A3 show the percentage difference between women and men with completed tertiary education.

Looking at the figure and the table, it is clear that all countries have passed the dotted line indicating a $0 \%$ difference. Considering the 27 nations together (and adjusting for population size), the difference between genders in Europe has changed from $-3.28 \%$ to $8.93 \%$ between the oldest and the youngest cohort, indicating that the slight male advantage has become a female advantage. In twelve of the examined countries women had a higher proportion of completed tertiary education in the earliest cohort, with Lithuania (7.52\%), Sweden (8.68\%), and Estonia (10.93\%) showing especially high levels of initial difference. Looking at the lower and upper ends, Austria, Germany, the United Kingdom, and Switzerland were the last to show a clear female advantage, as by the youngest cohort the difference was near or less than $5 \%$ in these nations, with a marginal $0.29 \%$ for the Swiss. The largest female tertiary advantage of near or above $20 \%$ was achieved by Poland (19.42\%), Estonia (20.62\%), and Slovenia (21.43\%). 
Erát: Educational assortative mating and the decline of hypergamy in 27 European countries

\section{Figure 1: Difference in proportion of women and men with completed tertiary education, by country and cohort, percentages}

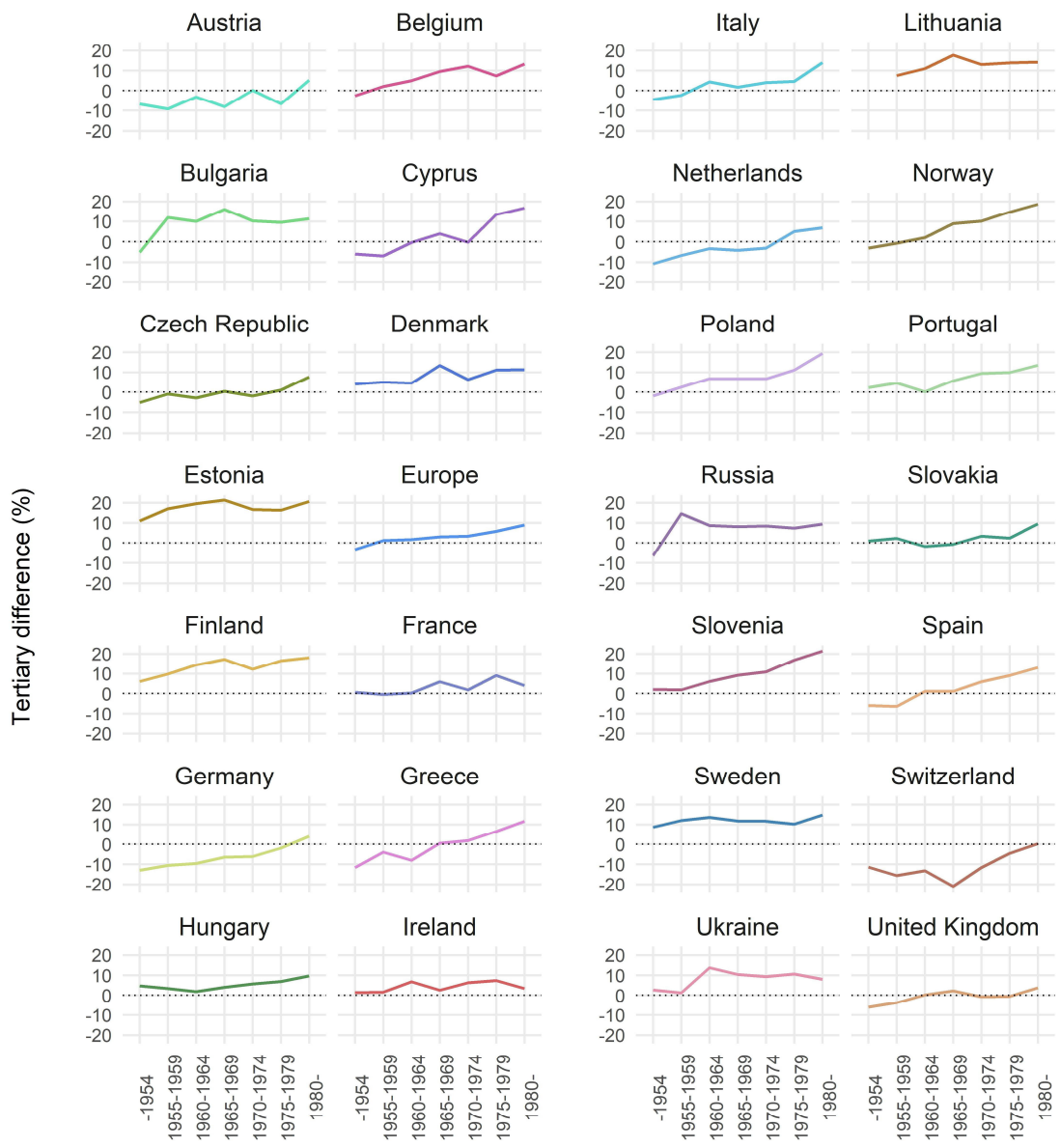

Cohorts

Note: The figure shows the difference in the percentage of men and women with tertiary education (Women - Men). Values over 0 indicate that the percentage of women with tertiary education is higher than the percentage of men. Data for Lithuania was only available from the cohort of 1955-1959. Data for Europe consists of pooled 27-country data with additional weighting to correct for population size bias.

Source: European Social Survey 1-9, author's edit. 


\section{Figure 2: $\quad$ Female educational advantage (F-index), by country and cohort}

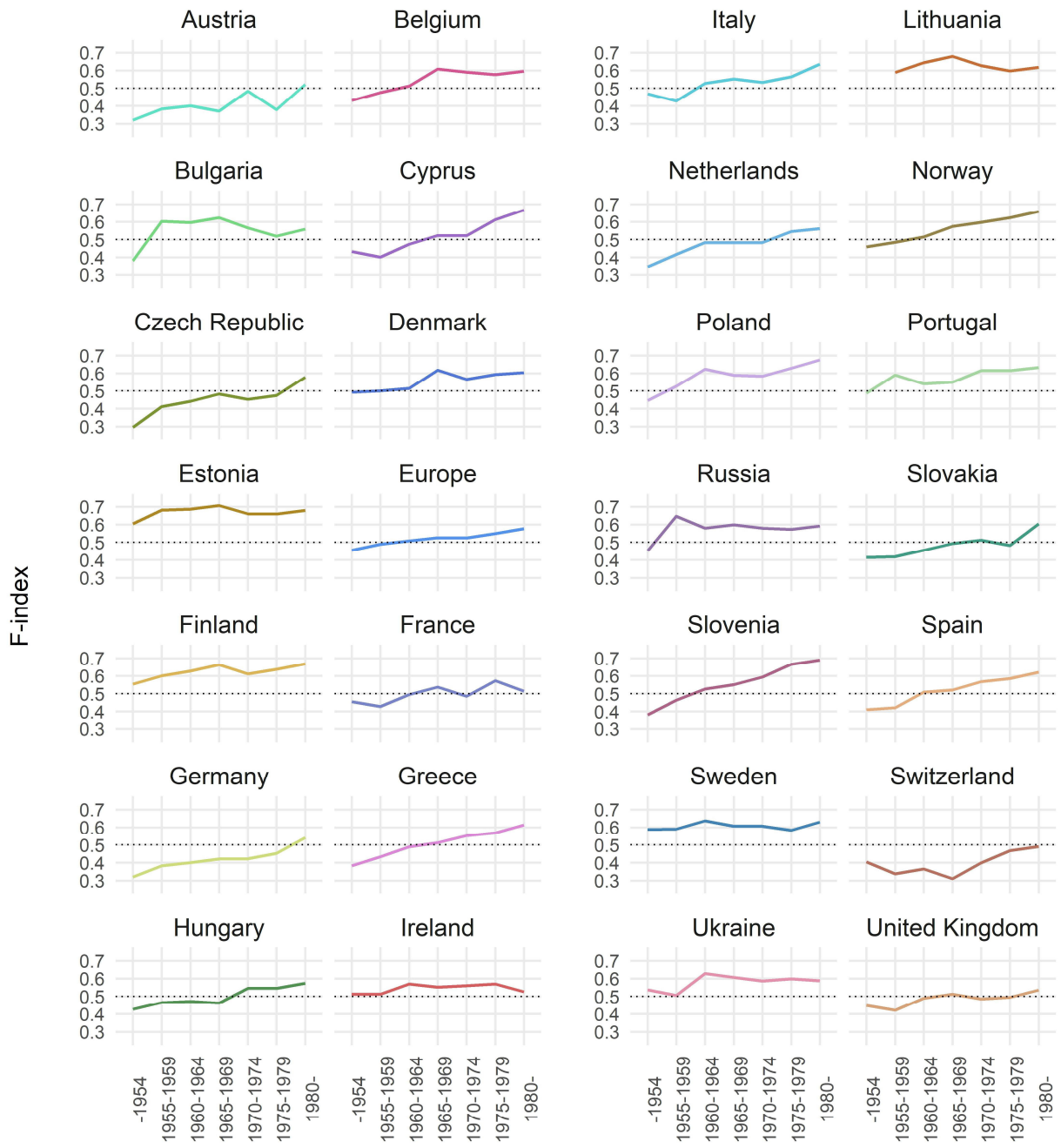

\section{Cohorts}

Note: The F-index shows the probability that of a randomly selected man and woman from a given population, the woman has a higher level of education. A value higher than 0.5 indicates a female advantage. Data for Lithuania was only available from the cohort of 1955-1959. Data for Europe consists of pooled 27-country data with additional weighting to correct for population size bias. Source: European Social Survey 1-9, author's edit. 
All in all, we can conclude that Esteve, García-Román, and Permanyer (2012) and De Hauw, Grow, and Van Bavel (2017) were right in their assessment that, generally, in Europe the growing percentage of women with upper-level education surpasses that of men, on some occasions by a considerable amount. In agreement with De Hauw, Grow, and Van Bavel (2017), Switzerland, Germany, and Austria show no substantial female advantage, which further highlights these countries as late adopters of the overall trend in Europe.

While the proportion of highly educated men and women is a strong indicator of changes in the educational composition of a given country, the previously discussed measure of female educational advantage (F-index) can give a more complete picture. Figure 2 and Table A-4 show the progression of this index through the cohorts. At first glance, the trends correspond well with the assessment of tertiary education, hinting that changes in tertiary education are responsible for the overall educational structure of the genders in Europe.

In the oldest cohort the probability of a randomly chosen woman having a higher level of completed education than a randomly picked man was just below fifty-fifty (0.45), but saw an increase, resulting in a F-index value of 0.58 for the pooled European sample by the cohort of those born in or after 1980. While this change might not seem substantial, it indicates that women gained an educational advantage over men even when taking all educational levels into consideration.

Although countries like the Czech Republic (0.30), Austria (0.32), Germany (0.32), and the Netherlands $(0.35)$ had a visible male advantage $(\mathrm{F}<0.50)$ early on, all nations followed the general European trend of an increasing female educational advantage, with more than half of them passing the line indicating educational equality $(\mathrm{F}=0.5)$ by the cohort of 1965-1969. Most notably, none of the selected countries experienced a consistent decline in the F-index, meaning that in the 27 nations there seems to be no sign of a return of male educational primacy. By the youngest cohort only the Swiss (0.49) displayed a minor remaining male advantage, while the highest F-index values were observed in Poland (0.67), Estonia (0.68), and Slovenia (0.69), although it should be noted that for fifteen countries the value was still equal to or above 0.60 . 


\section{Figure 3: $\quad$ The prevalence of hypergamy $(\mathrm{H})$, by country and cohort}

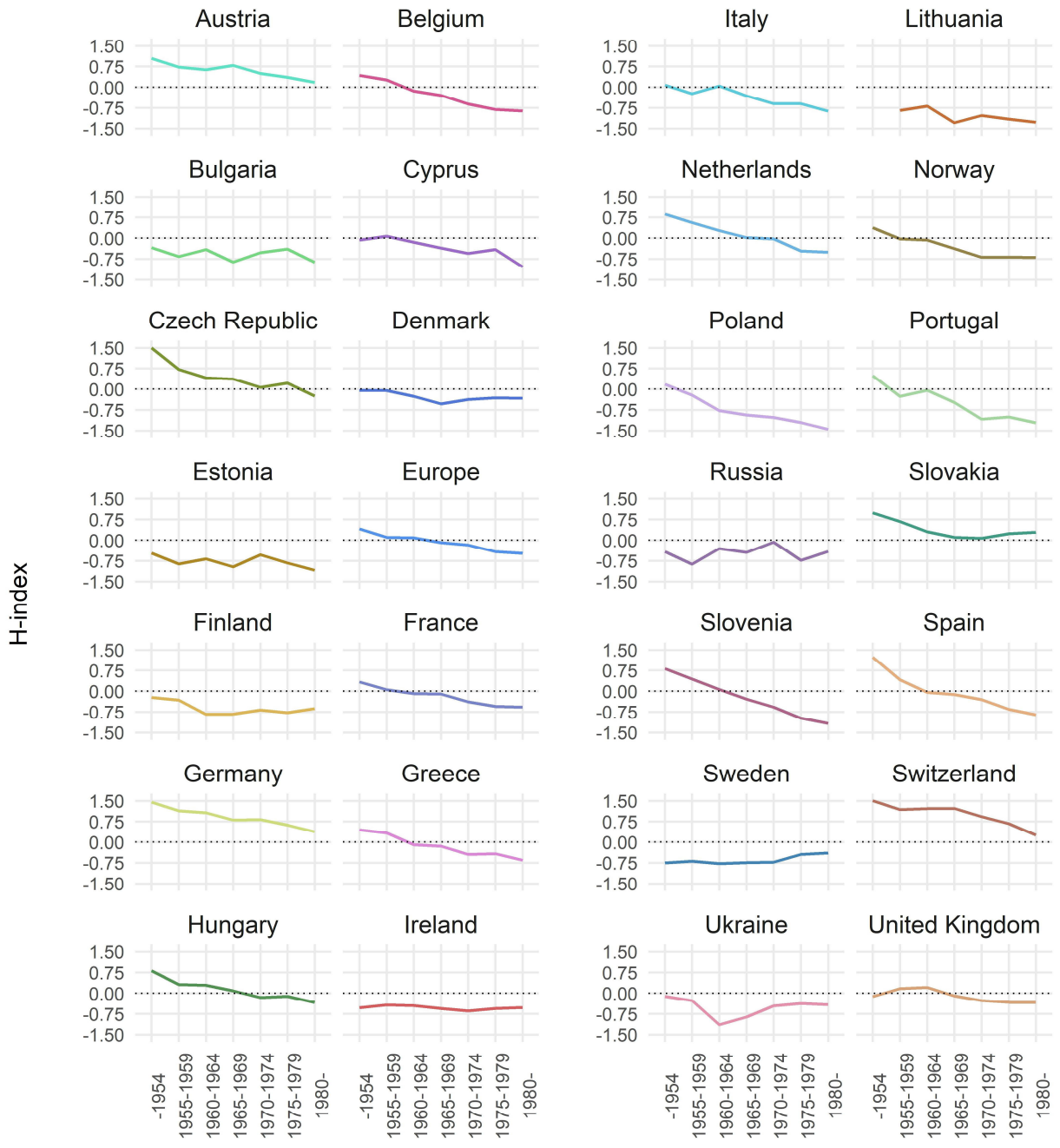

\section{Cohorts}

Note: The H-index shows the log of the number of hypergamous couples divided by the number of hypogamous couples. Values below zero indicate a higher number of educationally hypogamous partnerships amongst heterogamous unions. Data for Lithuania was only available from the cohort of 1955-1959. Data for Europe consists of pooled 27-country data with additional weighting to correct for population size bias.

Source: European Social Survey 1-9, author's edit. 
Is the progression of the female educational advantage in line with previous results? Even though prior studies used different samples, ${ }^{4}$ all the presented results align well with them. In Esteve, García-Román, and Permanyer (2012) and Esteve et al. (2016), all European countries showed a clear female advantage, aside from Germany in the former study, which, according to our data, achieved it by the latest cohort. In a more detailed country-specific examination, De Hauw, Grow, and Van Bavel (2017) also find Switzerland to have a generally lower F-index value than all other nations, which our results corroborate, with trends showing a steady increase for the Swiss as well.

What does this mean for men and women in the relationship market? Mainly, as women overtake men education-wise, the relationship market restructures in a way that makes hypogamy more likely, paving the way for the decline of hypergamy. To examine the weakening of hypergamy across Europe, first, Figure 3 and Table A-5 present the trends of the prevalence of hypergamy (H-index). As the H-index shows the log of the number of hypergamous couples divided by the number of hypogamous couples, a value lower than zero means that in non-homogamous unions there is a greater number of couples where women have an educational advantage.

Once again, a similar trend can be seen for all 27 examined countries, indicating a general decline in hypergamy. According to the pooled sample the emergence of hypogamy is notable, as the value of the $\mathrm{H}$-index has decreased from 0.41 to -0.48 in Europe. The detailed country-specific tendencies show that in 23 nations out of 27, hypogamy took over by the youngest cohort. This was especially the case in Portugal $(-1.21)$, Lithuania $(-1.28)$, and Poland $(-1.45)$, where hypogamy overcame traditional unions by the largest degree, as De Hauw, Grow, and Van Bavel (2017) also note it in their earlier results. Meanwhile, Austria (0.17), Switzerland (0.26), and Germany (0.37), with the addition of Slovakia (0.29), were again shown to lag behind the common trend, as in these countries hypergamy was still dominant, even in the youngest cohort. To summarize, the presented results confirm previous findings in the literature.

\footnotetext{
${ }^{4}$ Esteve, García-Román, and Permanyer (2012) use census data from IPUMS and examine persons between the ages of 25 and 34. Esteve et al. (2016) employ census and survey data (IPUMS, Demographic and Health Surveys, European Labour Force Surveys, EU-Statistics on Income and Living Conditions, Generations and Gender Surveys, South Korean census data), again for individuals aged 25-34 years. De Hauw, Grow, and Van Bavel (2017) work with data from the European Social Survey waves 1-6, and the International Institute for Applied Systems Analysis/Vienna Institute of Demography, for women aged 25-34 years and men aged 27-36 years.
} 
Figure 4: Correlation between female educational advantage (F-index) and prevalence of hypergamy (H-index)

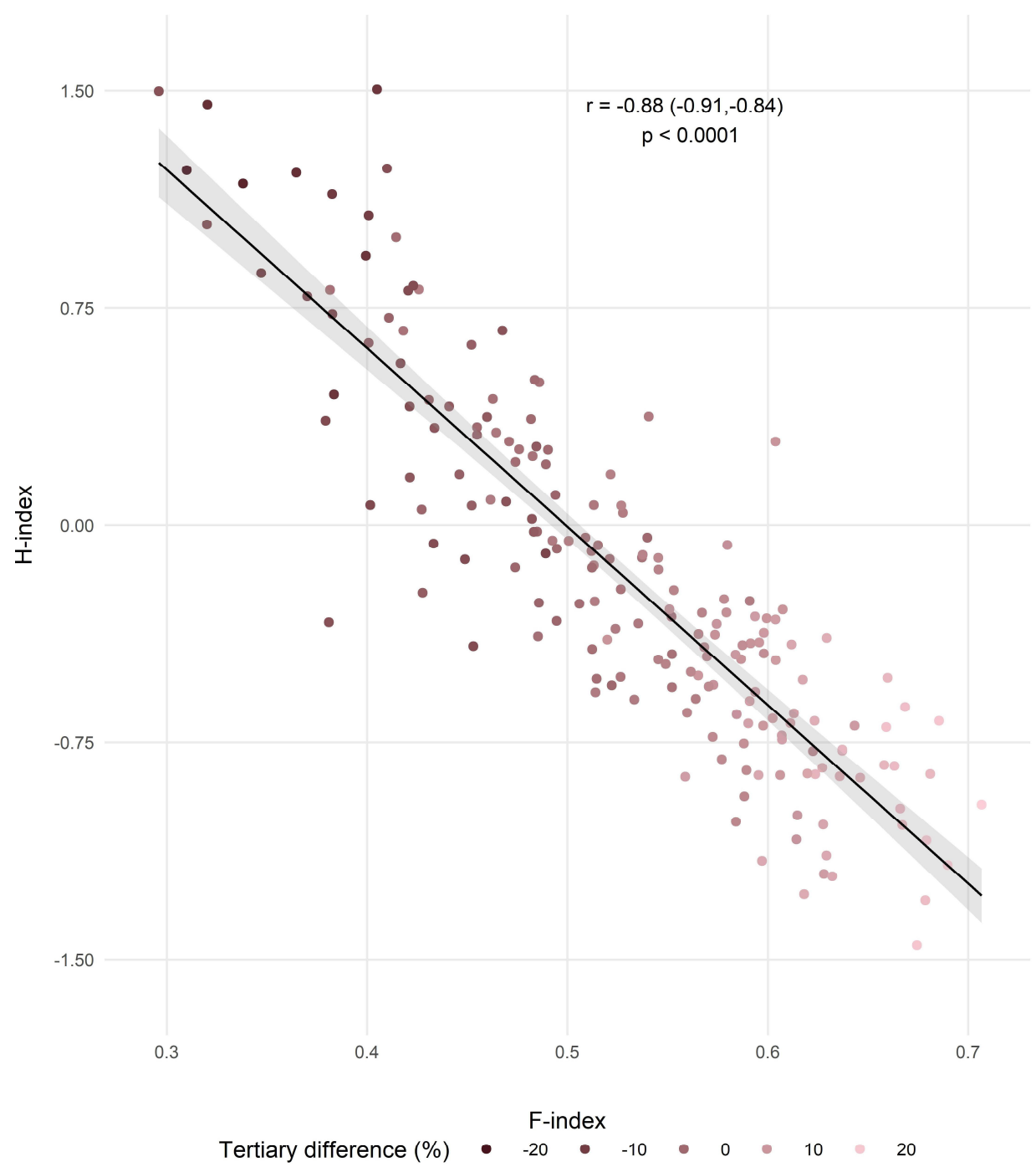

Note: $r$ indicates Pearson's correlation coefficient, with $95 \%$ confidence intervals provided in the parentheses (bootstrapped). The figure's colour is determined by the difference in the percentage of men and women with tertiary education (Women - Men). Source: European Social Survey 1-9, author's edit. 
While the descriptive results suggest that the increase in the female educational advantage of women is associated with the decline of hypergamy, it is worthwhile to look at this assumption more closely. Arriving at the main hypothesis of this current study, Esteve, García-Román, and Permanyer (2012) and Esteve et al. (2016) assume a strong, negative linear relationship between the two indices. Although country-specific examinations would be ideal, the low number of data points (seven per country) does not allow any reliable assessment of the association for individual nations. Therefore, we created a merged figure containing all cohort-specific tertiary difference, F-index values, and $\mathrm{H}$-index values per the 27 countries. To test the main hypothesis and to go beyond the simple scatterplot presented by earlier studies, we also calculated the correlation between the F-index and H-index (Pearson's) and also applied a linear trend line with a confidence interval (Figure 4). Additionally, colours were assigned to the observations based on the previously discussed tertiary difference values between women and men, enabling a simultaneous examination of the three measures.

In Figure 4 the negative linear relationship between female educational advantage and the prevalence of hypergamy is clearly visible, as higher values of the F-index are associated with lower values of the $\mathrm{H}$-index. The correlation measure also confirms this $(r=-0.88, p<0.0001)$, even with the $95 \%$ confidence intervals considered. This suggests that the two indices are indeed negatively connected, as Esteve, García-Román, and Permanyer (2012) and Esteve et al. (2016) proposed. This finding also corroborates the results of De Hauw, Grow, and Van Bavel's (2017) multilevel regression modelling, as they reveal that women's likelihood of partnering upwards declined as the gender gap in education reversed in favour of women. The inclusion of the differences in tertiary education between the genders acted in the expected way, as the data indicates that the negative linear trend is accompanied by an increasing gap in tertiary education in favour of women, signified by the progressive change in the colours of the figure's data points. 


\section{Figure 5: Correlation between female educational advantage ( $F$-index) and prevalence of hypergamy (H-index) for the oldest and youngest cohort, by country}

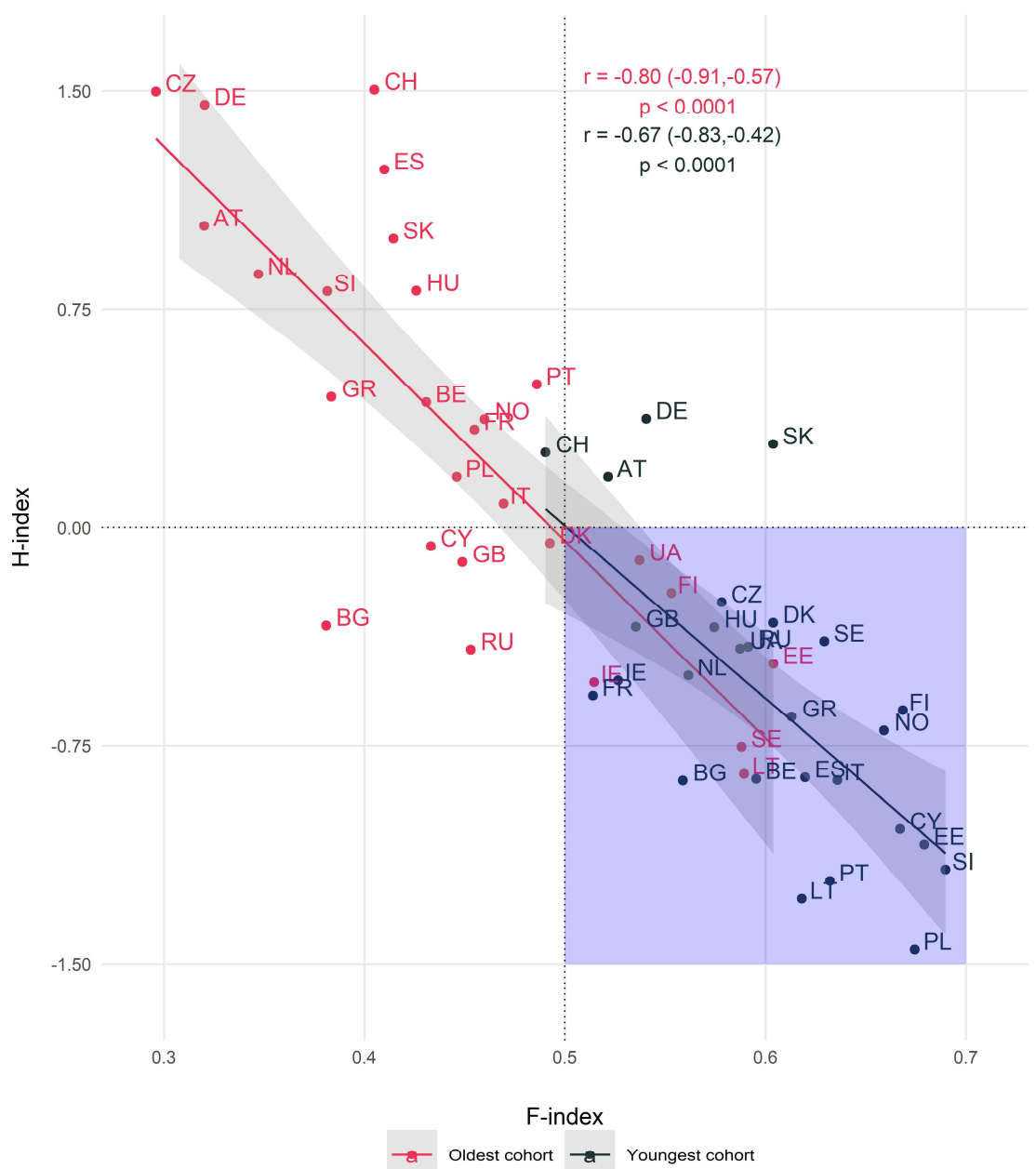

Note: $r$ indicates Pearson's correlation coefficient, with $95 \%$ confidence intervals provided in the parentheses (bootstrapped). Data for Lithuania was only available from the cohort of 1955-1959.

Abbreviations: $\mathrm{AT}=$ Austria, $\mathrm{BE}=$ Belgium, $\mathrm{BG}=$ Bulgaria, $\mathrm{CH}=$ Switzerland, $\mathrm{CY}=\mathrm{Cyprus}, \mathrm{CZ}=\mathrm{Cz}$ ech Republic, $\mathrm{DE}=\mathrm{Germany}, \mathrm{EE}$ $=$ Estonia, $\mathrm{ES}=$ Spain, $\mathrm{FI}=$ Finland, $\mathrm{FR}=\mathrm{France}, \mathrm{GB}=$ United Kingdom, $\mathrm{GR}=$ Greece, $\mathrm{HU}=$ Hungary, IE $=$ Ireland, IT = Italy, LT = Lithuania, $\mathrm{NL}=$ Netherlands, $\mathrm{NO}=$ Norway, $\mathrm{PL}=$ Poland, $\mathrm{PT}=$ Portugal, $\mathrm{RU}=$ Russia, $\mathrm{SE}=\mathrm{Sweden}, \mathrm{SI}=\mathrm{Slovenia}, \mathrm{UA}=\mathrm{Ukraine}$ The two overlapping nations in the area of female advantage are Ukraine and Russia.

Source: European Social Survey 1-9, author's edit. 
Lastly, to look at the current state of the growing female educational advantage and the decline of hypergamy in Europe, we focused on the youngest cohort (those born in or after 1980) of all the countries in Figure 5, with the values for the oldest available cohort presented as a reference. As visible during the examination of the merged figure, the correlation between the F-index and $\mathrm{H}$-index still holds for both the oldest $(\mathrm{r}=-0.80, \mathrm{p}$ $<0.0001)$ and the youngest $(\mathrm{r}=-0.67, \mathrm{p}<0.0001)$ cohort.

The purple area, bordered by a vertical and horizontal dotted line, which we named the 'area of female advantage', highlights the space in which the oldest or youngest cohort of a given country has a female educational advantage $(\mathrm{F}>0.5)$ and hypogamy has overtaken hypergamy $(\mathrm{H}<0)$. Apart from four nations, all countries were in this area by the youngest cohort, with the countries generally following the previously noted negative linear trend, again confirming previous studies and the current work's hypothesis. While most countries show a considerable difference between the position of the oldest and youngest cohort, it should be emphasized that the oldest examined cohorts of Ukraine, Finland, Ireland, Estonia, Sweden, and Lithuania were already in the highlighted area of female advantage, making them unique in this regard.

As shown earlier, Portugal, Lithuania, and Poland stand out with their low levels of hypergamy, which is also apparent when only looking at data for the youngest cohort. These countries are joined by Cyprus, Estonia, and Slovenia, with comparably high levels of female educational advantage and hypogamous couples. At the other end, Switzerland stands out among the four nations that are still not in the accented area of female advantage, as men still have a slightly higher average level of education, paired with a higher number of hypergamous unions. In the other three (Austria, Germany, and Slovakia), although women already have an educational advantage (F-index $<0.5$ ), married and non-married relationships do not yet reflect this clearly $(\mathrm{H}$-index $>0)$.

\section{Summary}

In this paper we examined how the increasing advantage of women in education is associated with the changing composition of the relationship market and the decline of educational hypergamy in 27 European countries. The main aim was to verify the previous results of Esteve, Permanyer, and García-Román (2012), Esteve et al. (2016), and De Hauw, Grow, and Van Bavel (2017), using a detailed cohort perspective. The findings indeed corroborate the cited evidence from recent years, strengthening the implication that the decline in hypergamy is associated with the new conditions in the relationship market.

Considering the current work and previous studies, it can be concluded that hypergamy is becoming increasingly infrequent in Europe. On the contrary, educational 
hypogamy is rapidly advancing to second position, behind homogamy, which hints at what the future holds for educational assortative mating patterns in Europe: homogamy, followed by hypogamy, with a relatively low number of traditional hypergamous unions.

The presented results highlight possible future areas of inquiry. First, with the diffusion of hypogamy, will the effects associated with these types of union change? Previously, we discussed Becker's economic theory that educational hypogamy increases the probability of relationship dissolution due to the independence effect (Becker, Landes, and Michael 1977; Becker 1981, 1985; Oppenheimer 1997), and that these partnerships might be harder to maintain in gender-traditional societies as they go against the prevailing norms (West and Zimmerman 1987; Brines 1994; Eagly and Wood 1999; Tichenor 2005). However, recent empirical evidence suggests that these effects may decline or even disappear when these relationships become more common and therefore accepted (Theunis et al. 2018). Second, if educational hypergamy becomes rare, will the uncommon nature of hypergamous unions have an effect on relationships? Again, Theunis et al. (2018) hint that this might be the case, as under circumstances in which hypogamy is the second most prevalent type of partnership, hypergamous unions are more likely to dissolve.

Third, if the change is primarily driven by structural factors, how do individual preferences and societal norms react to it? As previously noted, the dual-earner arrangement, and therefore women's socioeconomic resources such as education, might become preferred, as they offer an additional level of flexibility in the face of unforeseen events, and possibly a higher level of well-being (Oppenheimer 1977, 1994, 1997; Sweeney 2002). While numerous factors influence individual preferences, it can be speculated that if non-hypergamous relationships emerge due to the structural conditions of the relationship market, individuals might be faced with the advantages of unions in which women have higher (both in absolute and relative terms) socioeconomic resources, which could in turn influence overall partner-selection preferences. Regarding norms, while Esteve et al.'s results suggest that women's educational advantage is indeed associated with more gender-egalitarian attitudes (2016), others note that the change in overall gender norms is uneven and stalled (England 2010). As nations differ from each other in their level of traditionality, future research should focus more on whether the decline in hypergamy truly means the weakening of traditional gender norms for women and men in these countries. In summary, the study of educational assortative mating still has many unanswered questions, and there is a continual need to assess multi-country and nation-specific trends and processes.

Although the results are based on multiple waves of a representative survey programme, the limitations of this current work should be mentioned as well. Primarily, as we have looked at the trends through cohorts, certain biases (such as cohort or education-specific mortality, relationship formation and dissolution) might be present in 
our findings. Second, the structure of the relationship market and couples' relative completed educational attainment were assessed with a simple three-way categorization, which shrouds finer details and developments, such as homogamy trends among the higher educated (Esteve and Cortina 2006; Grave and Schmidt 2012; Katrňák and Manea 2020). Third, the calculations assume that an individual primarily chooses a partner from his or her cohort group, which would mean that the opportunities are static for someone looking for a partner, and newly entered younger or already-present older participants in the relationship market are ignored. Finally, while education is linked to overall socioeconomic status it is also determined by several other factors, such as income, occupation, and prestige; therefore, education-based arguments need further verification, using other indicators to achieve a better understanding of assortative mating and its implications.

\section{Acknowledgements}

This work was supported by the Higher Education Institutional Excellence Programme of the Ministry for Innovation and Technology in Hungary, within the framework of the 4th thematic programme "Enhancing the Role of Domestic Companies in the Reindustrialization of Hungary" of the University of Pécs [20765/3/2018/FEKUT STRAT].

This paper was written as part of the project titled EFOP-3.6.3-VEKOP-16-201700007 - Young Researchers From Talented Students - Fostering Scientific Careers In Higher Education, which is cofinanced by the European Union (European Social Fund) within the framework of Programme Széchenyi 2020.

I would especially like to thank my PhD supervisor, Zsolt Spéder, for his help and guidance. 


\section{References}

Autor, D.H. (2014). Skills, education, and the rise of earnings inequality among the 'other 99 percent'. Science 344(6186): 843-851. doi:10.1126/science.1251868.

Becker, G.S. (1973). A theory of marriage: Part I. Journal of Political Economy 81(4): 813-846. doi:10.1086/260084.

Becker, G.S. (1974). A theory of marriage: Part II. Journal of Political Economy 82(2): S11-S26. doi:10.1086/260287.

Becker, G.S. (1981). A treatise on the family. Cambridge: Harvard University Press.

Becker, G.S. (1985). Human capital, effort and the sexual division of labor. Journal of Labor Economics 3(1): S33-S58. doi:10.1086/298075.

Becker, G.S., Landes, E.M., and Michael, R.T. (1977). An economic analysis of marital instability. Journal of Political Economy 85(6): 1141-1187. doi:10.1086/260631.

Berger, V. (2019). Mediatizált szerelem. A Tinder fenomenológiája. Replika 2019(113): 63-87. doi:10.32564/113.5.

Birkelund, G.E. and Heldal, J. (2003). Who marries whom? Educational homogamy in Norway. Demographic Research 8(1): 1-30. doi:10.4054/DemRes.2003.8.1.

Blau, P.M. (1977). A macrosociological theory of social structure. The American Journal of Sociology 83(1): 26-54. doi:10.1086/226505.

Blossfeld, G.J. (2014). Educational assortative mating and divorce: A longitudinal analysis of the influences of education on the divorce rate for different educational matches. Paper presented at the annual meeting of the Population Association of America, 2014. https://paa2014.princeton.edu/papers/141481.

Blossfeld, H.P. and Timm, A. (2003). Educational systems as marriage markets in modern societies: a conceptual framework. In: Blossfeld, H.P. and Timm, A. (eds.). Who marries whom? Educational systems as marriage markets in modern societies. Dordrecht: Kluwer Academic Publishers: 1-18. doi:10.1007/978-94007-1065-8_1.

Borkotoky, K. and Gupta, A.K. (2016). Trends and patterns of educational homogamy in India: a marriage cohort analysis. International Journal of Population Research 2016: 1-8. doi:10.1155/2016/8562942.

Breen, R. (2010). Educational expansion and social mobility in the $20^{\text {th }}$ century. Social Forces 89(2): 365-388. doi:10.1353/sof.2010.0076. 
Breen, R., Luijkx, R., Müller, W., and Pollak, R. (2009). Nonpersistent inequality in educational attainment: Evidence from eight European countries. American Journal of Sociology 114(5): 1475-1521. doi:10.1086/595951.

Brines, J. (1994). Economic dependency, gender, and the division of labor at home. American Journal of Sociology 100(3): 652-688. doi:10.1086/230577.

Bruch, E.E. and Newman, M.E.J. (2018). Aspirational pursuit of mates in online dating markets. Science Advances 4(8): eaap9815. doi:10.1126/sciadv.aap9815.

Bukodi, E. (2002). Ki kivel (nem) házasodik? A partnerszelekciós minták változása az egyéni életútban és a történeti időben. Szociológiai Szemle 12(2): 28-58.

Cabré, A. (1993). Volverán tórtolos y cigüeñas. In: Garrido, L. and Gil Calvo, E. (eds.). Estrategias familiares. Madrid: Alianza Editorial: 113-131.

Correia, H.R. (2003). Higher male educational hypergamy: Evidence from Portugal. Journal of Biosocial Science 35(2): 303-313. doi:10.1017/S0021932003003031.

De Hauw, Y., Grow, A., and Van Bavel, J. (2017). The reversed gender gap in education and assortative mating in Europe. European Journal of Population 33(4): 445474. doi:10.1007/s10680-016-9407-z.

Dribe, M. and Nystedt, P. (2013). Educational homogamy and gender-specific earnings: Sweden, 1990-2009. Demography 50(4): 1197-1216. doi:10.1007/s13524-0120188-7.

Eagly, A.H., and Wood, W. (1999). The origins of sex differences in human behavior: Evolved dispositions versus social roles. American Psychologist 54(6): 408-423. doi:10.1037/0003-066X.54.6.408.

Eichenberg, C., Huss, J., and Küsel, C. (2017). From online dating to online divorce: An overview of couple and family relationships shaped through digital media. Contemporary Family Therapy 39(4): 249-260. doi:10.1007/s10591-017-9434-x.

England, P. (2010). The gender revolution: uneven and stalled. Gender and Society 24(2): 149-166. doi:10.1177/0891243210361475.

Esteve, A.P. and Cortina, C. (2006). Changes in educational assortative mating in contemporary Spain. Demographic Research 14(17): 405-428. doi:10.4054/Dem Res.2006.14.17.

Esteve, A., García-Román, J., and Permanyer, I. (2012). The gender-gap reversal in education and its effect on union formation: The end of hypergamy? Population 
and Development Review 38(3): 535-546. doi:10.1111/j.1728-4457.2012.005 15.x.

Esteve, A., Schwartz, C.R., Van Bavel, J., Permanyer, I., Klesment, M., and GarcíaRomán, J. (2016). The end of hypergamy: Global trends and implications. Population and Development Review 42(4): 615-625. doi:10.1111/padr.12012.

European Social Survey (2014). Weighting European Social Survey data. https://www.europeansocialsurvey.org/docs/methodology/ESS_weighting_data_ 1.pdf.

European Social Survey (2020). Data and documentation. https://www.european socialsurvey.org/data/.

Frimmel, W., Halla, M., and Winter-Ebmer, R. (2013). Assortative mating and divorce: Evidence from Austrian register data. Journal of the Royal Statistical Society: Series A (Statistics in Society) 176: 907-929. doi:10.1111/j.1467-985X. 2012.01070.x.

Fukuda, S., Yoda, S., and Mogi, R. (2019). Educational assortative mating in Japan: Evidence from the 1980-2010 census. (Working Paper Series E; 29). Tokyo: National Institute of Population and Social Security. https://pdfs.semantic scholar.org/ae8e/836dc0114fe35628a9d5f3bcca0c4bc76bd5.pdf.

Ganguli, I., Hausmann, R., and Viarengo, M. (2014). Marriage, education and assortative mating in Latin America. Applied Economics Letters 21(12): 806-811. doi:10.10 80/13504851.2013.849375.

Grave, B.S. and Schmidt, C.M. (2012). The dynamics of assortative mating in Germany. (Ruhr Economic Paper; 346). Bochum: Ruhr-Universität Bochum. https://papers.ssrn.com/sol3/Delivery.cfm/SSRN_ID2122485_code343237.pdf?a bstractid $=2122485 \&$ mirid $=1 \&$ type $=2$.

Henz, U. and Mills, C. (2017). Social class origin and assortative mating in Britain, 19492010. Sociology 52(1): 1-20. doi:10.1177/0038038517726479.

Hout, M. (1982). The association between husbands' and wives' occupations in twoearner families. American Journal of Sociology 88(2): 397-409. doi:10.1086/ 227679 .

Huckfeldt, R.R. (1983). Social contexts, social networks, and urban neighbourhoods: Environmental constraints on friendship choice. American Journal of Sociology 89(3): 651-669. doi:10.1086/227908. 
Kalmijn, M. (1991). Shifting boundaries: Trends in religious and educational homogamy. American Sociological Review 56(2): 786-800. doi:10.2307/2096256.

Kalmijn, M. (1994). Assortative mating by cultural and economic occupational status. American Journal of Sociology 100(2): 422-452. doi:10.1086/230542.

Kalmijn, M. (1998). Intermarriage and homogamy: Causes, patterns, trends. Annual Review of Sociology 24(1): 395-421. doi:10.1146/annurev.soc.24.1.395.

Kalmijn, M. (2003). Union disruption in the Netherlands: Opposing influences of task specialization and assortative mating? International Journal of Sociology 33(2): 36-64. doi:10.1080/15579336.2003.11770266.

Kalmijn, M. and Flap, H. (2001). Assortative meeting and mating: unintended consequences of organized settings for partner choices. Social Forces 79(4): 1289-1312. doi:10.1353/sof.2001.0044.

Katrňák, T. (2008). Educational assortative mating in the Czech Republic, Slovakia and Hungary between 1976 and 2003. Sociológia 40(3): 236-257.

Katrňák, T. and Manea, B.C. (2020). Change in prevalence or preference? Trends in educational homogamy in six European countries in a time of educational expansion. Social Science Research 2020(91): 102460. doi:10.1016/j.ssresearch. 2020.102460.

Kerckhoff, A.C. (1964). Patterns of homogamy and the field of eligibles. Social Forces 42(3): 289-297. doi:10.1093/sf/42.3.289.

Kreager, D.A., Cavanagh, S.E., Yen, J., and Yu, M. (2014). 'Where have all the good men gone?' Gendered interactions in online dating. Journal of Marriage and Family 76(2): 387-410. doi:10.1111/jomf.12072.

Krzyzanowska, M. and Mascie-Taylor, C.G.N. (2014). Educational and social class assortative mating in fertile British couples. Annals of Human Biology 41(6): 561567. doi:10.3109/03014460.2014.903996.

Laumann, E.O., Gagnon, J.H., Michael, R.T., and Michaels, S. (1994). The social organization of sexuality: Sexual practices in the United States. Chicago: University of Chicago Press.

Lyngstad, T.H. (2004). The impact of parents' and spouses' education on divorce rates in Norway. Demographic Research 10(5): 121-142. doi:10.4054/DemRes.2004. 10.5 . 
Maenpaa, E. (2015). Socio-economic homogamy and its effects on the stability of cohabiting unions. Finnish Yearbook of Population Research L 2015 Supplement. doi:10.23979/fypr.51043.

Maenpaa, E. and Jalovaara, M. (2014). Homogamy in socio-economic background and education, and the dissolution of cohabiting unions. Demographic Research 30(65): 1769-1792. doi:10.4054/DemRes.2014.30.65.

Mare, R.D. (1991). Five decades of educational assortative mating. American Sociological Review 56(1): 15-32. doi:10.2307/2095670.

McFarland, D. (1975). Models of marriage formation and fertility. Social Forces 54(1): 66-83. doi:10.1093/sf/54.1.66.

Nomes, E. and Van Bavel, J. (2017). Education and marriage: the shift from hypergamy to hypogamy in Belgium, a 20th century cohort analysis. Revue Quetelet / Quetelet Journal 5(2): 37-67. doi:10.14428/rqj2017.05.02.02.

Oppenheimer, V.K. (1977). The sociology of women's economic role in the family. American Sociological Review 42(3): 387-406. doi:10.2307/2094746.

Oppenheimer, V.K. (1994). Women's rising employment and the future of the family in industrial societies. Population and Development Review 20(2): 293-342. doi: $10.2307 / 2137521$.

Oppenheimer, V.K. (1997). Women's employment and the gain to marriage: The specialization and trading model. Annual Review of Sociology 23(1): 431-453. doi:10.1146/annurev.soc.23.1.431.

Parsons, T. (1942). Age and sex in the social structure of the United States. In: Parsons, T. (ed.). Essays in sociological theory. Glencoe: Free Press: 89-104. doi:10.23 07/2085686.

Parsons, T. (1955a). The American family: Its relations to personality and to the social structure. In: Parsons, T. and Bales, R.F. (eds.). Family, socialization and interaction process. Glencoe: Free Press: 35-133.

Parsons, T. (1955b). Family structure and the socialization of the child. In: Parsons, T. and Bales, R.F. (eds.). Family, socialization and interaction process. Glencoe: Free Press: 3-35.

Pesando, L.M. (2019). Educational assortative mating, development, and inequality in sub-Saharan Africa. Paper presented at the annual meeting of the Population Association of America, 2019. http://paa2019.populationassociation.org/ uploads/190634. 
Posselt, J.R. and Grodsky, E. (2017). Graduate education and social stratification. Annual Review of Sociology 43(1): 353-378. doi:10.1146/annurev-soc-081715-074324.

Qian, Y. (2016). Gender asymmetry in educational and income assortative marriage. Journal of Marriage and Family 79(2): 318-336. doi:10.1111/jomf.12372.

Rosenfeld, M.J. (2002). Measures of assimilation in the marriage market: Mexican Americans 1970-1990. Journal of Marriage and Family 64(1): 152-162. doi:10.1111/j.1741-3737.2002.00152.x.

Sorokin, P.A. (1927). Social mobility. London: Harper and Brothers.

South, S.J. (1991). Sociodemographic differentials in mate selection preferences. Journal of Marriage and Family 53(4): 928-940. doi:10.2307/352998.

Stevens, G. (1991). Propinquity and educational homogamy. Sociological Forum 6(4): 715-726. doi:10.1007/BF01114409.

Sweeney, M.M. (2002). Two decades of family change: The shifting economic foundations of marriage. American Journal of Sociology 67(1): 132-147. doi:10. $2307 / 3088937$.

Sweeney, M.M. and Cancian, M. (2001). The changing importance of economic prospects for assortative mating. (California Center for Population Research OnLine Working Paper Series; CCPR-008-01). Los Angeles: California Center for Population Research. http://citeseerx.ist.psu.edu/viewdoc/download?doi=10.1.1. $202.4866 \&$ rep $=$ rep $1 \&$ type $=$ pdf.

Teachman, J.D. (2002). Stability across cohorts in divorce risk factors. Demography 39(2): 331-351. doi:10.1353/dem.2002.0019.

Theunis, L., Schnor, C., Willaert, D., and Van Bavel, J. (2018). His and her education and marital dissolution: Adding a contextual dimension. European Journal of Population 34(4): 663-687. doi:10.1007/s10680-017-9448-y.

Tichenor, V.J. (2005). Maintaining men's dominance: Negotiating identity and power when she earns more. Sex Roles 53(3-4): 191-205. doi:10.1007/s11199-005$5678-2$.

Van Bavel, J. (2012). The reversal of gender inequality in education, union formation, and fertility in Europe. Vienna Yearbook of Population Research 10: 127-154. doi:10.1553/populationyearbook2012s127. 
Vincent-Lancrin, S. (2008). The reversal of gender inequalities in higher education: an on-going trend. In: OECD (eds.). Higher education to 2030, Volume 1, Demography. OECD Publishing: 265-298. doi:10.1787/9789264040663-11-en.

West C. and Zimmerman, D. (1987). Doing gender. Gender and Society 1(2): 125-151. doi: $10.1177 / 0891243287001002002$.

Winch, R.F. (1958). Mate-selection. New York: Harper and Brothers. 
Erát: Educational assortative mating and the decline of hypergamy in 27 European countries

\section{Appendix} Table A-1: Number of respondents for the calculation of tertiary differences and
the index of female educational advantage (F-index), weighted

\begin{tabular}{|c|c|c|c|c|c|c|c|}
\hline Country & -1954 & 1955-1959 & $1960-1964$ & 1965-1969 & $1970-1974$ & 1975-1979 & -1980 \\
\hline Austria & 555 & 640 & 1,252 & 1,162 & 1,024 & 846 & 1,430 \\
\hline Belgium & 571 & 957 & 1,325 & 1,385 & 1,195 & 1,060 & 1,354 \\
\hline Bulgaria & 130 & 617 & 850 & 832 & 845 & 832 & 1,200 \\
\hline Cyprus & 89 & 377 & 456 & 417 & 414 & 423 & 645 \\
\hline Czech Republic & 575 & 713 & 1,222 & 1,479 & 1,706 & 1,356 & 2,032 \\
\hline Denmark & 511 & 724 & 990 & 987 & 883 & 717 & 577 \\
\hline Estonia & 316 & 754 & 1,106 & 1,193 & 1,246 & 1,175 & 1,960 \\
\hline Finland & 752 & 998 & 1,461 & 1,458 & 1,186 & 1,210 & 1,639 \\
\hline France & 579 & 914 & 1,294 & 1,490 & 1,387 & 1,218 & 1,661 \\
\hline Germany & 821 & 1,431 & 2,481 & 2,431 & 1,825 & 1,526 & 2,094 \\
\hline Greece & 437 & 800 & 801 & 913 & 906 & 760 & 481 \\
\hline Hungary & 557 & 804 & 915 & 1,200 & 1,350 & 1,311 & 1,607 \\
\hline Ireland & 560 & 922 & 1,480 & 1,850 & 1,840 & 1,823 & 2,661 \\
\hline Italy & 143 & 143 & 411 & 685 & 689 & 589 & 1,022 \\
\hline Lithuania & - & 180 & 728 & 982 & 859 & 739 & 1,591 \\
\hline Netherlands & 730 & 1,055 & 1,514 & 1,541 & 1,460 & 1,154 & 1,408 \\
\hline Norway & 622 & 840 & 1,228 & 1,335 & 1,313 & 1,025 & 1,149 \\
\hline Poland & 679 & 1,043 & 1,129 & 1,142 & 1,167 & 1,293 & 1,642 \\
\hline Portugal & 562 & 881 & 1,295 & 1,411 & 1,337 & 1,229 & 1,357 \\
\hline Russia & 254 & 712 & 984 & 1,023 & 1,034 & 1,004 & 1,559 \\
\hline Slovakia & 340 & 689 & 808 & 805 & 823 & 882 & 1,018 \\
\hline Slovenia & 490 & 704 & 1,012 & 1,111 & 929 & 936 & 1,074 \\
\hline Spain & 506 & 760 & 1,345 & 1,664 & 1,643 & 1,619 & 1,798 \\
\hline Sweden & 683 & 832 & 1,247 & 1,440 & 1,233 & 1,205 & 1,449 \\
\hline Switzerland & 605 & 903 & 1,336 & 1,468 & 1,298 & 1,024 & 1,311 \\
\hline Ukraine & 359 & 757 & 922 & 795 & 778 & 822 & 906 \\
\hline United Kingdom & 714 & 1,089 & 1,797 & 1,819 & 1,745 & 1,430 & 2,109 \\
\hline Europe (pooled sample) & 13,013 & 22,099 & 33,364 & 35,822 & 33,598 & 30,712 & 42,107 \\
\hline
\end{tabular}

Note: Data for Lithuania was only available from the cohort of 1955-1959. Data for Europe consists of pooled 27-country data with additional weighting to correct for population size bias.

Source: European Social Survey 1-9. 
Table A-2: Number of respondents for the calculation of the prevalence of hypergamy (H-index), weighted

\begin{tabular}{|c|c|c|c|c|c|c|c|}
\hline Country & -1954 & 1955-1959 & 1960-1964 & 1965-1969 & 1970-1974 & 1975-1979 & -1980 \\
\hline Austria & 471 & 517 & 986 & 868 & 742 & 529 & 833 \\
\hline Belgium & 439 & 694 & 983 & 1,065 & 906 & 745 & 828 \\
\hline Bulgaria & 106 & 495 & 697 & 666 & 652 & 593 & 667 \\
\hline Cyprus & 82 & 326 & 395 & 365 & 324 & 273 & 330 \\
\hline Czech Republic & 443 & 539 & 964 & 1,191 & 1,371 & 976 & 1,147 \\
\hline Denmark & 407 & 566 & 769 & 730 & 677 & 534 & 347 \\
\hline Estonia & 224 & 514 & 771 & 839 & 915 & 850 & 1,259 \\
\hline Finland & 557 & 735 & 1,055 & 1,058 & 895 & 869 & 1,076 \\
\hline France & 477 & 724 & 975 & 1,122 & 1,076 & 940 & 1,125 \\
\hline Germany & 639 & 1,051 & 1,783 & 1,793 & 1,301 & 978 & 1,167 \\
\hline Greece & 387 & 684 & 669 & 705 & 609 & 433 & 197 \\
\hline Hungary & 443 & 622 & 644 & 898 & 969 & 848 & 847 \\
\hline Ireland & 472 & 746 & 1,133 & 1,382 & 1,315 & 1,067 & 1,298 \\
\hline Italy & 113 & 123 & 312 & 460 & 460 & 350 & 438 \\
\hline Lithuania & - & 124 & 554 & 779 & 659 & 571 & 1,102 \\
\hline Netherlands & 615 & 841 & 1,236 & 1,247 & 1,183 & 867 & 964 \\
\hline Norway & 489 & 650 & 895 & 983 & 986 & 717 & 758 \\
\hline Poland & 534 & 813 & 899 & 936 & 964 & 952 & 1,042 \\
\hline Portugal & 482 & 708 & 1,042 & 1,083 & 992 & 809 & 640 \\
\hline Russia & 178 & 507 & 715 & 737 & 732 & 691 & 855 \\
\hline Slovakia & 250 & 533 & 645 & 624 & 639 & 595 & 543 \\
\hline Slovenia & 408 & 584 & 821 & 898 & 717 & 581 & 539 \\
\hline Spain & 410 & 626 & 1,054 & 1,257 & 1,162 & 974 & 840 \\
\hline Sweden & 147 & 383 & 633 & 788 & 697 & 716 & 897 \\
\hline Switzerland & 468 & 698 & 1,011 & 1,143 & 1,011 & 713 & 766 \\
\hline Ukraine & 262 & 574 & 718 & 604 & 639 & 594 & 580 \\
\hline United Kingdom & 556 & 782 & 1,261 & 1,251 & 1,188 & 932 & 1,164 \\
\hline Europe (pooled sample) & 10,060 & 16,732 & 24,865 & 26,488 & 24,563 & 20,758 & 23,927 \\
\hline
\end{tabular}

Note: Data for Lithuania was only available from the cohort of 1955-1959. Data for Europe consists of pooled 27-country data with additional weighting to correct for population size bias.

Source: European Social Survey 1-9. 
Erát: Educational assortative mating and the decline of hypergamy in 27 European countries

Table A-3: Difference in proportion of women and men with completed tertiary education percentages

\begin{tabular}{|c|c|c|c|c|c|c|c|}
\hline Country & -1954 & 1955-1959 & 1960-1964 & 1965-1969 & $1970-1974$ & 1975-1979 & $1980-$ \\
\hline Austria & -6.84 & -9.21 & -3.23 & -8.16 & 0.15 & -6.66 & 5.17 \\
\hline Belgium & -2.67 & 2.06 & 4.91 & 9.56 & 12.11 & 7.38 & 13.27 \\
\hline Bulgaria & -5.13 & 11.92 & 9.98 & 15.97 & 10.19 & 9.53 & 11.34 \\
\hline Cyprus & -6.04 & -6.95 & -0.34 & 4.02 & -0.17 & 13.39 & 16.77 \\
\hline Czech Republic & -5.14 & -0.98 & -2.85 & 0.42 & -1.95 & 0.97 & 7.61 \\
\hline Denmark & 3.96 & 4.89 & 4.49 & 13.38 & 6.30 & 11.10 & 11.28 \\
\hline Estonia & 10.93 & 16.91 & 19.50 & 21.31 & 16.59 & 16.22 & 20.62 \\
\hline Finland & 6.06 & 9.73 & 14.38 & 17.24 & 12.16 & 16.45 & 18.08 \\
\hline France & 0.58 & -0.49 & 0.26 & 5.89 & 1.77 & 9.01 & 4.02 \\
\hline Germany & -12.96 & -10.57 & -9.63 & -6.48 & -6.14 & -1.90 & 4.05 \\
\hline Greece & -11.58 & -3.88 & -8.00 & 0.54 & 1.82 & 6.51 & 11.68 \\
\hline Hungary & 4.77 & 3.33 & 1.88 & 4.04 & 5.72 & 6.83 & 9.66 \\
\hline Ireland & 1.37 & 1.58 & 6.79 & 2.58 & 6.28 & 7.36 & 3.41 \\
\hline Italy & -4.55 & -2.39 & 4.32 & 1.70 & 3.97 & 4.58 & 14.02 \\
\hline Lithuania & - & 7.52 & 10.93 & 17.72 & 12.98 & 13.79 & 14.16 \\
\hline Netherlands & -10.74 & -6.71 & -3.37 & -4.18 & -3.11 & 5.05 & 6.83 \\
\hline Norway & -3.07 & -0.70 & 2.02 & 8.93 & 10.11 & 14.74 & 18.70 \\
\hline Poland & -1.94 & 2.47 & 6.75 & 6.69 & 6.67 & 11.05 & 19.42 \\
\hline Portugal & 2.15 & 4.44 & 0.16 & 5.70 & 9.43 & 9.84 & 13.52 \\
\hline Russia & -6.41 & 14.59 & 8.71 & 8.03 & 8.38 & 7.35 & 9.34 \\
\hline Slovakia & 1.00 & 2.36 & -1.81 & -0.75 & 3.41 & 2.45 & 9.53 \\
\hline Slovenia & 2.04 & 1.81 & 5.98 & 9.18 & 10.81 & 16.87 & 21.43 \\
\hline Spain & -5.81 & -6.30 & 1.15 & 1.13 & 5.93 & 9.03 & 13.03 \\
\hline Sweden & 8.68 & 12.04 & 13.65 & 11.84 & 11.73 & 10.21 & 14.75 \\
\hline Switzerland & -11.37 & -15.57 & -13.23 & -21.05 & -11.69 & -4.56 & 0.29 \\
\hline Ukraine & 2.64 & 1.19 & 13.78 & 10.30 & 9.32 & 10.61 & 8.00 \\
\hline United Kingdom & -6.16 & -3.76 & 0.16 & 2.16 & -0.76 & -0.60 & 3.72 \\
\hline Europe (pooled sample) & -3.28 & 1.23 & 1.74 & 3.01 & 3.39 & 5.74 & 8.93 \\
\hline
\end{tabular}

Note: Values show the difference in the percentage of men and women with tertiary education (Women - Men). Values over 0 indicate that the percentage with tertiary education is higher among women than among men. Data for Lithuania was only available from the cohort of 1955-1959. Data for Europe consists of pooled 27-country data with additional weighting to correct for population size bias. Source: European Social Survey $1-9$. 
Table A-4: Index of female educational advantage (F-index)

\begin{tabular}{|c|c|c|c|c|c|c|c|}
\hline Country & -1954 & 1955-1959 & 1960-1964 & 1965-1969 & $1970-1974$ & 1975-1979 & $1980-$ \\
\hline Austria & 0.32 & 0.38 & 0.40 & 0.37 & 0.48 & 0.38 & 0.52 \\
\hline Belgium & 0.43 & 0.48 & 0.51 & 0.61 & 0.59 & 0.58 & 0.60 \\
\hline Bulgaria & 0.38 & 0.60 & 0.60 & 0.62 & 0.57 & 0.52 & 0.56 \\
\hline Cyprus & 0.43 & 0.40 & 0.47 & 0.52 & 0.52 & 0.61 & 0.67 \\
\hline Czech Republic & 0.30 & 0.41 & 0.44 & 0.48 & 0.45 & 0.47 & 0.58 \\
\hline Denmark & 0.49 & 0.50 & 0.51 & 0.62 & 0.57 & 0.59 & 0.60 \\
\hline Estonia & 0.60 & 0.68 & 0.69 & 0.71 & 0.66 & 0.66 & 0.68 \\
\hline Finland & 0.55 & 0.60 & 0.63 & 0.66 & 0.61 & 0.64 & 0.67 \\
\hline France & 0.45 & 0.43 & 0.49 & 0.54 & 0.49 & 0.57 & 0.51 \\
\hline Germany & 0.32 & 0.38 & 0.40 & 0.42 & 0.42 & 0.45 & 0.54 \\
\hline Greece & 0.38 & 0.43 & 0.49 & 0.51 & 0.55 & 0.57 & 0.61 \\
\hline Hungary & 0.43 & 0.46 & 0.47 & 0.46 & 0.55 & 0.55 & 0.57 \\
\hline Ireland & 0.51 & 0.51 & 0.57 & 0.55 & 0.56 & 0.57 & 0.53 \\
\hline Italy & 0.47 & 0.43 & 0.53 & 0.55 & 0.53 & 0.56 & 0.64 \\
\hline Lithuania & - & 0.59 & 0.64 & 0.68 & 0.63 & 0.60 & 0.62 \\
\hline Netherlands & 0.35 & 0.42 & 0.48 & 0.48 & 0.48 & 0.55 & 0.56 \\
\hline Norway & 0.46 & 0.48 & 0.52 & 0.57 & 0.60 & 0.62 & 0.66 \\
\hline Poland & 0.45 & 0.53 & 0.62 & 0.59 & 0.58 & 0.63 & 0.67 \\
\hline Portugal & 0.49 & 0.59 & 0.54 & 0.55 & 0.61 & 0.61 & 0.63 \\
\hline Russia & 0.45 & 0.65 & 0.58 & 0.60 & 0.58 & 0.57 & 0.59 \\
\hline Slovakia & 0.41 & 0.42 & 0.45 & 0.49 & 0.51 & 0.48 & 0.60 \\
\hline Slovenia & 0.38 & 0.46 & 0.53 & 0.55 & 0.59 & 0.67 & 0.69 \\
\hline Spain & 0.41 & 0.42 & 0.51 & 0.52 & 0.57 & 0.58 & 0.62 \\
\hline Sweden & 0.59 & 0.59 & 0.64 & 0.61 & 0.61 & 0.58 & 0.63 \\
\hline Switzerland & 0.40 & 0.34 & 0.36 & 0.31 & 0.40 & 0.47 & 0.49 \\
\hline Ukraine & 0.54 & 0.51 & 0.63 & 0.61 & 0.59 & 0.60 & 0.59 \\
\hline United Kingdom & 0.45 & 0.42 & 0.49 & 0.51 & 0.49 & 0.49 & 0.54 \\
\hline Europe (pooled sample) & 0.45 & 0.49 & 0.51 & 0.53 & 0.52 & 0.55 & 0.58 \\
\hline
\end{tabular}

Note: The F-index shows the probability that from a randomly selected man and woman from a given population, the woman has a higher level of education. A value higher than 0.5 indicates a female advantage. Data for Lithuania was only available from the cohort of 1955-1959. Data for Europe consists of pooled 27-country data with additional weighting to correct for population size bias. Source: European Social Survey 1-9. 
Erát: Educational assortative mating and the decline of hypergamy in 27 European countries

Table A-5: Index of the prevalence of hypergamy (H-index)

\begin{tabular}{|c|c|c|c|c|c|c|c|}
\hline Country & -1954 & 1955-1959 & $1960-1964$ & 1965-1969 & $1970-1974$ & $1975-1979$ & $1980-$ \\
\hline Austria & 1.04 & 0.73 & 0.63 & 0.79 & 0.50 & 0.36 & 0.17 \\
\hline Belgium & 0.43 & 0.26 & -0.14 & -0.29 & -0.61 & -0.81 & -0.86 \\
\hline Bulgaria & -0.34 & -0.67 & -0.41 & -0.86 & -0.52 & -0.40 & -0.87 \\
\hline Cyprus & -0.06 & 0.07 & -0.15 & -0.36 & -0.55 & -0.41 & -1.04 \\
\hline Czech Republic & 1.50 & 0.72 & 0.41 & 0.37 & 0.07 & 0.22 & -0.26 \\
\hline Denmark & -0.05 & -0.05 & -0.26 & -0.53 & -0.38 & -0.32 & -0.33 \\
\hline Estonia & -0.47 & -0.86 & -0.68 & -0.97 & -0.53 & -0.83 & -1.09 \\
\hline Finland & -0.23 & -0.32 & -0.84 & -0.83 & -0.68 & -0.77 & -0.63 \\
\hline France & 0.34 & 0.05 & -0.08 & -0.10 & -0.38 & -0.55 & -0.58 \\
\hline Germany & 1.45 & 1.14 & 1.07 & 0.81 & 0.83 & 0.62 & 0.37 \\
\hline Greece & 0.45 & 0.34 & -0.10 & -0.15 & -0.45 & -0.42 & -0.65 \\
\hline Hungary & 0.81 & 0.32 & 0.29 & 0.09 & -0.15 & -0.11 & -0.34 \\
\hline Ireland & -0.53 & -0.43 & -0.45 & -0.56 & -0.65 & -0.56 & -0.52 \\
\hline Italy & 0.08 & -0.23 & 0.04 & -0.32 & -0.60 & -0.60 & -0.87 \\
\hline Lithuania & - & -0.85 & -0.69 & -1.30 & -1.03 & -1.16 & -1.28 \\
\hline Netherlands & 0.87 & 0.56 & 0.27 & 0.02 & -0.02 & -0.46 & -0.51 \\
\hline Norway & 0.37 & -0.02 & -0.07 & -0.38 & -0.69 & -0.68 & -0.70 \\
\hline Poland & 0.17 & -0.22 & -0.78 & -0.94 & -1.02 & -1.21 & -1.45 \\
\hline Portugal & 0.49 & -0.26 & -0.04 & -0.48 & -1.09 & -1.00 & -1.21 \\
\hline Russia & -0.42 & -0.87 & -0.30 & -0.44 & -0.07 & -0.73 & -0.41 \\
\hline Slovakia & 0.99 & 0.67 & 0.31 & 0.10 & 0.07 & 0.24 & 0.29 \\
\hline Slovenia & 0.81 & 0.43 & 0.07 & -0.29 & -0.58 & -0.98 & -1.17 \\
\hline Spain & 1.23 & 0.41 & -0.04 & -0.12 & -0.30 & -0.65 & -0.86 \\
\hline Sweden & -0.75 & -0.69 & -0.78 & -0.74 & -0.73 & -0.45 & -0.39 \\
\hline Switzerland & 1.50 & 1.18 & 1.22 & 1.23 & 0.93 & 0.67 & 0.26 \\
\hline Ukraine & -0.11 & -0.27 & -1.14 & -0.86 & -0.46 & -0.37 & -0.41 \\
\hline United Kingdom & -0.12 & 0.16 & 0.21 & -0.09 & -0.27 & -0.33 & -0.34 \\
\hline Europe (pooled sample) & 0.41 & 0.11 & 0.09 & -0.08 & -0.18 & -0.42 & -0.48 \\
\hline
\end{tabular}

Note: The $\mathrm{H}$-index shows the log of the number of hypergamous couples divided by the number of hypogamous couples. Values below zero indicate a higher number of educationally hypogamous partnerships among heterogamous unions. Data for Lithuania was only available from the cohort of 1955-1959. Data for Europe consists of pooled 27-country data with additional weighting to correct for population size bias.

Source: European Social Survey 1-9. 